\title{
Assessment of Immunomodulatory Activity of the Biofield Energy Treated Novel Herbomineral Formulation After Oral Administration in Female Sprague Dawley Rats
}

\author{
${ }^{1}$ Trivedi Global, Inc., Henderson, Nevada, USA \\ ${ }^{2}$ Trivedi Science Research Laboratory Pvt. Ltd., Bhopal, India \\ Email address: \\ publication@trivedieffect.com (S. Jana) \\ *Corresponding author
}

Mahendra Kumar Trivedi ${ }^{1}$, Alice Branton ${ }^{1}$, Dahryn Trivedi ${ }^{1}$, Gopal Nayak ${ }^{1}$, Cathryn Dawn Nykvist ${ }^{1}$, Celine Lavelle ${ }^{1}$, Daniel Paul Przybylski ${ }^{1}$, Dianne Heather Vincent ${ }^{1}$, Dorothy Felger ${ }^{1}$, Douglas Jay Konersman ${ }^{1}$, Elizabeth Ann Feeney ${ }^{1}$, Jay Anthony Prague ${ }^{1}$, Joanne Lydia Starodub ${ }^{1}$, Karan Rasdan ${ }^{1}$, Karen Mie Strassman ${ }^{1}$, Leonid Soboleff ${ }^{1}$, Maire Mayne ${ }^{1}$, Mary M. Keesee ${ }^{1}$, Padmanabha Narayana Pillai ${ }^{1}$, Pamela Clarkson Ansley ${ }^{1}$, Ronald David Schmitz ${ }^{1}$, Sharyn Marie Sodomora ${ }^{1}$, Sambhu Charan Mondal ${ }^{2}$, Snehasis Jana ${ }^{2, *}$

\section{To cite this article:}

Mahendra Kumar Trivedi, Alice Branton, Dahryn Trivedi, Gopal Nayak, Cathryn Dawn Nykvist, Celine Lavelle, Daniel Paul Przybylski, Dianne Heather Vincent, Dorothy Felger, Douglas Jay Konersman, Elizabeth Ann Feeney, Jay Anthony Prague, Joanne Lydia Starodub, Karan Rasdan, Karen Mie Strassman, Leonid Soboleff, Maire Mayne, Mary M. Keesee, Padmanabha Narayana Pillai, Pamela Clarkson Ansley, Ronald David Schmitz, Sharyn Marie Sodomora, Sambhu Charan Mondal, Snehasis Jana. Assessment of Immunomodulatory Activity of the Biofield Energy Treated Novel Herbomineral Formulation After Oral Administration in Female Sprague Dawley Rats. International Journal of Biomedical Engineering and Clinical Science. Vol. 3, No. 6, 2017, pp. 90-99.

doi: 10.11648/j.ijbecs.20170306.14

Received: October 30, 2017; Accepted: November 14, 2017; Published: November 30, 2017

\begin{abstract}
The use of an herbomineral formulation in the healthcare sector for different chronic diseases is gaining popularity due to its fewer side-effects, high safety profile, and cost effectiveness. A new proprietary herbomineral formulation was formulated, consisting of four essential ingredients viz. herbal (ashwagandha root extract) and minerals (zinc chloride, magnesium gluconate, and sodium selenate). The objective of this study was to evaluate the immunomodulatory effect of the Biofield Energy Treated test formulation on female Sprague Dawley (SD) rats. The test formulation was divided into two parts; one was represented as control, while the other part was treated with the Biofield Energy Healing Treatment remotely by renowned Biofield Energy Healers (The Trivedi Effect ${ }^{\mathbb{B}}$ ) and defined as the Biofield Energy Treated formulation. The effect of the test formulation was monitored using humoral immune response, delayed type hypersensitivity, hematology, biochemistry, relative organ weight, and histopathology. The primary hemagglutination (HA) antibody titre level was significantly $(p \leq 0.05)$ increased by $185.88 \%$ in the Biofield Energy Treated group (G3); while $41.18 \%$ increased in the untreated test formulation group (G4) as compared to the disease control group (G2). The secondary HA titre was significantly increased by $540 \%(p \leq 0.001)$ and $166.7 \%$ in the G3 and G4 groups, respectively as compared to the G2 group. The secondary HA titre was also increased significantly $(p \leq 0.05)$ by $193 \%$ in the Biofield Energy Treated group per se at day -15 (G6), as compared to the G2 group. The paw volume data showed an alteration in the G3 and G6 groups as compared to the G2 group. The platelet count was significantly increased by $11.16 \%$ and $8.69 \%$ in the G3 and G4 groups, respectively as compared to the G2 group. The magnesium level was increased by $9.31 \%$ in the G3 group as compared to the G2 group. The uric acid was significantly reduced by $23.88 \%$ in the G3 group; while it was increased by $17.47 \%$ in the G4 group as compared to the G2 group. Since, the relative organ weight and histopathological findings did not produce any signs of toxicity as compared to the normal control group (G1). These data suggested that the Biofield Energy Treated herbomineral formulation was found to be safe and showed better immunomodulatory response as compared to the untreated formulation. Thus, it is assumed that the Biofield Energy Treated herbomineral formulation could be better and more useful to boost-up the immune system in healthy human and patients.
\end{abstract}


Keywords: Biofield Energy Healing Treatment, The Trivedi Effect ${ }^{\circledR}$, Immunomodulation, Humoral Immune Response, Herbomineral Formulation, Hematology, Stress Management, Anti-aging

\section{Introduction}

Natural products derived from plants and minerals are always regarded as the primary source for new herbomineral formulation for maintaining the overall health [1]. Medicinal plant-derived drugs are continuously gaining popularity in the developed and developing countries alike, due to their natural origin and less side effects. Many traditional and complementary medicines are derived from medicinal plants, minerals, and organic matter, which are commonly used for the prevention and treatment of many diseases [2]. According to World Health Organization (WHO), medicinal plants are always being the target of most of the pharmaceutical companies for new formulations [3], due to the presence of one or more active phytoconstituents [4]. With this aspect, a new proprietary herbomineral formulation was formulated with a combination of the herb ashwagandha root extract and three minerals viz. zinc chloride, magnesium gluconate, and sodium selenate. All the components have been reported for important pharmacological activities, such as ashwagandha (Withania somnifera) that belongs to the family Solanaceae, commonly used as alternative therapies $[5,6]$ due to the presence of pharmacologically active molecule like withanolides [7]. Apart from its common attributes such as antibacterial, immunomodulatory and antitumor effects, many clinical and preclinical data have been available with respect to the immunomodulatory impact $[8,9]$. The importance of minerals such as selenium, zinc, and magnesium to modulate the immune system has been welldefined [10]. The scientific research has been documented that due to the presence of minerals, herbal medicines have been found to exhibit a high level of phagocytic index and improved antibody titre [11]. These formulations can be used for better therapeutic effect in immune compromised patients that are affected by the cardiovascular diseases, age and stress related diseases, cancer, and autoimmune disorders. Along with the herbomineral formulations, the Biofield Energy Healers in this study have used Energy Medicine (Biofield Energy Healing Treatment) as a complementary and alternative approach to study the impact of Biofield Energy Treatment on the herbomineral formulation for its immunomodulatory potential in female Sprague Dawley rats.

In recent years, several scientific reports and clinical trials have shown the useful effects of Biofield Energy Treatment, which has shown enhanced immune function in cases of cervical cancer patients with therapeutic touch [12], massage therapy [13], etc. Complementary and Alternative Medicine (CAM) is now rising as preferred model of treatment, among which Biofield Therapy (or Healing Modalities) is one approach that has been reported with several benefits to enhance the physical, mental and emotional human wellness. The National Center of Complementary and Integrative
Health (NCCIH) has recognized and accepted Biofield Energy Healing as a Complementary and Alternative Medicine (CAM) health care approach in addition to other therapies, medicines and practices such as natural products, deep breathing, yoga, Tai Chi, Qi Gong, chiropractic/osteopathic manipulation, meditation, massage, special diets, homeopathy, progressive relaxation, guided imagery, acupressure, acupuncture, relaxation techniques, hypnotherapy, healing touch, movement therapy, pilates, rolfing structural integration, mindfulness, Ayurvedic medicine, traditional Chinese herbs and medicines, naturopathy, essential oils, aromatherapy, Reiki, and cranial sacral therapy. Human Biofield Energy has subtle energy that has the capacity to work in an effective manner [14]. Complementary and Alternative Medicine (CAM) therapies have been practiced worldwide with reported clinical benefits in different health disease profiles [15]. This energy can be harnessed and transmitted by individuals into living and nonliving things via the process of Biofield Energy Healing. Biofield Energy Treatment (The Trivedi Effect ${ }^{\mathbb{B}}$ ) outcomes have been reported in numerous peer-reviewed science journals with significant outcomes in many scientific fields such as cancer research [16, 17], altered antimicrobial sensitivity of pathogenic microbes in microbiology [18-21], genetics [22, 23], altered physical and chemical properties of pharmaceutical compounds [24-27], improved overall growth and yield of plants in agricultural science [28-31], and changing the structure of the atom in relation to various metals, ceramics, polymers and chemicals in materials science [32-35]. The authors evaluated the impact of Biofield Energy Treatment (The Trivedi Effect ${ }^{\circledR}$ ) on the given herbomineral formulation in female Sprague Dawley rats, which might improve the immunomodulatory function with respect to the antibody titre, delayed type hypersensitivity reaction, hematological parameters, and serum biochemistry using standard assays.

\section{Materials and Methods}

\subsection{Chemicals and Reagents}

Pyrogallol and sodium carboxymethyl cellulose were purchased from Sigma Chemical Co. (St. Louis, MO). Ashwagandha (Withania somnifera) root extract powder was procured from Sanat Products Ltd., India. Zinc chloride and magnesium (II) gluconate hydrate were procured from TCI, Japan. Sodium selenate was procured from Alfa Aesar, U.S.A. Levamisole hydrochloride was procured from Sigma, U.S.A. All other chemicals used in this study were of analytical grade available locally.

\subsection{Laboratory Animals}

All the procedures and protocols were approved by 
Institutional Animal Ethics Committee (IAEC). All the animals were handled humanely with due regard for their welfare. Care of animals were complied with the regulations of Committee for the Purpose of Control and Supervision of Experiments on Animals (CPCSEA), Govt. of India. Randomly breed healthy female Sprague Dawley rats body weight ranges between 132-183 grams, were used for the study. All the animals were housed under standard experimental conditions, with room temperature $\left(22 \pm 3^{\circ} \mathrm{C}\right)$ and relative humidity (30\% to $70 \%$ ).

\subsection{Biofield Energy Healing Strategies}

The herbomineral test formulation was divided into two parts. One part of the test formulation was treated with Biofield Energy by renowned Biofield Energy Healers (also known as The Trivedi Effect ${ }^{(\mathbb{B}}$ ) and coded as the Biofield Energy Treated formulation, while the second part of the test formulation did not receive any sort of treatment and was defined as the untreated test formulation. This Biofield Energy Treatment was provided to the test formulation through a group of eighteen Biofield Energy Healers who participated in this study and performed the Biofield Energy Treatment to the test formulation remotely. Eleven Biofield Energy Healers were remotely located in the U.S.A, four were remotely located in Canada, and one of which was remotely located in UK, Russia and Ireland, while the test herbomineral formulation was located in the research laboratory of Dabur Research Foundation, New Delhi, India. This Biofield Energy Treatment was administered for 5 minutes through the Healer's Unique Energy Transmission process remotely to the test formulation under the laboratory conditions. Besides, one group of animals was also received Biofield Energy Treatment per se by Biofield Energy Healers under similar conditions. None of the Biofield Energy Healers in this study visited the laboratory in person, nor had any contact with the herbomineral samples. Further, the control group was treated with a "sham" healer for comparative purpose. The sham healer did not have any knowledge about the Biofield Energy Treatment. After that, the Biofield Energy Treated and untreated test formulations were returned in the similar sealed condition and kept in recommended storage condition.

\subsection{Antigen (Sheep RBC)}

The fresh sheep blood was collected aseptically from the jugular vein of a healthy sheep and transferred immediately to the heparinized tube. The collected erythrocytes were separated from plasma by centrifugation $\left(400 \mathrm{~g}, 10^{\circ} \mathrm{C}, 10\right.$ minutes), washed twice with the normal saline and then further diluted in saline and the samples were analyzed using Hematology analyzer (Abbott Model-CD-3700). Based on the number of erythrocytes, the samples were further diluted (using saline) before injecting to the rat [36].

\subsection{Experimental Procedure}

After 5 days of acclimatization, the animals were grouped
(G) based on the body weight. G1 (normal control) received oral suspension of $0.5 \%$ carboxy methyl cellulose-sodium salt via gavage. The G2 (disease control) received pyrogallol at a dose of $100 \mathrm{mg} / \mathrm{kg}$ through intraperitoneal (i.p.) route once daily for 7 days. The G3 animals received the Biofield Energy Treated test formulation (1105.005 mg/kg b.wt, p.o.). The G4 received untreated test formulation at the same dose orally, while the G5 received levamisole at a dose of 50 $\mathrm{mg} / \mathrm{kg}$ p.o. from day 1 to day 22. Further, the G6 received Biofield Energy Treatment group per se at day -15, without any test formulation. All the animals except normal control group received pyrogallol at a dose of $100 \mathrm{mg} / \mathrm{kg}$ through i.p. route once daily from day 1 to 7 . The animals were administered with the Biofield Energy Treated and untreated test formulation to the G3 and G4 animals, respectively, one hour before the pyrogallol challenge in the morning once daily for 22 days. The treatment was continued to all the tested groups ( $\mathrm{G} 1$ to $\mathrm{G} 6$ ) with $5 \mathrm{~mL} / \mathrm{kg}$ body weight dose volume. On day 7 and day 13, all the animals in G2-G6 except normal control (G1) were challenged with sheep red blood cells (sRBC) $\left(0.5 \times 10^{9} / 100 \mathrm{gm}\right.$; i.p.) as the antigenic material to sensitize them for immunological parameters. On the days $13^{\text {th }}$ and $20^{\text {th }}$, blood sample was collected from retroorbital plexus and subjected to hemagglutination test to evaluate the humoral immune response. On the same day, the animals were challenged with sheep RBC $\left(0.5 \times 10^{9}\right.$ cells $/ 50$ $\mu \mathrm{L} / \mathrm{rat}$ ) in sub-planter region and on $22^{\text {nd }}$ day (48 hours), paw volume was measured to evaluate cellular immune response. The body weight and food consumption were measured daily before treatment. On day 22, the animals were kept under fasting over night and on day 23; blood was collected again from retro-orbital plexus from each animal under isoflurane anaesthesia. Whole blood was analysed for haematological parameters and serum was analysed for serum biochemistry. At the end of the study; animals were euthanized by $\mathrm{CO}_{2}$ asphyxiation as per in-house approved standard protocol. Different organs of all animals were excised, weighed and preserved for histopathological analysis.

\subsection{Determination of Humoral Immune Response}

On day 13 and 20, blood was withdrawn from the retroorbital plexus of all antigenically challenged rats. Approximately $25 \mu \mathrm{L}$ of serum was serially diluted with 25 $\mu \mathrm{L}$ of phosphate-buffered saline. The $\operatorname{sRBC}\left(0.025 \times 10^{9}\right.$ cells) was added to each of these dilutions and incubated at $37^{\circ} \mathrm{C}$ for one hour. The rank of minimum dilution that exhibited hemagglutination (HA) was considered as an antibody titre. The level of antibody titre on day 13 of the experiment was considered as the primary humoral immune response and the day 20 of the experiment was considered as the secondary humoral immune response [37].

\subsection{Determination of Paw Volume (Delayed Type Hypersensitivity)}

The cellular immune response was assayed by the footpad reaction method. The edema was induced in the right paw of 
rats by injecting sRBC $\left(0.025 \times 10^{9}\right.$ cells $)$ in the sub-plantar region. The change in paw volume was assessed on digital plethysmometer (PanLab, Spain). The mean percentage increase in paw volume was considered as delayed type of hypersensitivity as an index of cell-mediated immunity. The volume of the left hind paw, injected similarly with phosphate-buffered saline, served as control.

\subsection{Determination of Hematological and Biochemical Parameters}

After fasting for 12 to 16 hours on day $23^{\text {rd }}$ of the experiment, blood was collected from the retro-orbital plexus using heparinized and non-heparinized capillary tubes. The non-heparinized capillary tube of blood was kept in plain bottle from which serum was collected and further stored for biochemical analysis. The heparinized tube containing blood was directly subjected for the estimation of various hematological parameters using standard instrument. The various hematological parameters such as hemoglobin $(\mathrm{Hb})$, red blood corpuscle (RBC), packed cell volume (PCV), mean corpuscular volume (MCV), mean corpuscular hemoglobin (MCH), mean corpuscular hemoglobin concentration (MCHC) and platelets were analyzed with blood samples. Further, the level of magnesium, blood urea nitrogen (BUN), creatinine, uric acid, calcium, phosphorus, potassium, sodium, and chloride ion concentration was analyzed in serum sample using Hematology analyzer (Abbott ModelCD-3700) [38].

\subsection{Determination of Body Weight and Feed Intake}

Body weight and feed intake of all the animals in various experimental groups were measured once daily before dosing. Briefly, the weight of daily feed supply and the leftover by the following day was recorded and the difference was taken as the daily feed intake. The average feed intake was computed for every three days of the experimental period [39].

\subsection{Clinical Sign and Symptoms}

All the animals were observed for the clinical signs and symptoms once daily in accordance with the in-house protocol [40]. Animals found in a moribund condition or enduring signs of severe distress was humanely euthanized. Abnormal findings were recorded with the time of onset and disappearance.

\subsection{Measurement of Relative Organ Weight and Histopathology}

At the end of the experiment, rats were dissected and the whole liver, kidneys, hearts, spleens, lungs, whole intestine, eyes, brain, and ovaries were excised, freed of fat, blotted with clean tissue paper, and then weighed. The organ to body weight ratio was determined by comparing the weight of each organ with the final body weight of each rat. Defined samples were placed in $10 \%$ neutral buffered formalin for histopathological examination as per standard protocol.

\subsection{Statistical Analysis}

Data were expressed as mean \pm standard error of mean (S.E.M.) and were subjected to one-way analysis of variance (ANOVA) followed by Dunnett's multiple range test and Student's $t$-test. Statistical significance was considered at $p<0.05$.

\section{Results and Discussion}

\subsection{Determination of Humoral Immune Response}

The results of primary and secondary humoral immune responses after oral administration of test formulation in female Sprague Dawley rats are summarized in the Table 1 . The primary mean hemagglutination (HA) antibody titre level was significantly $(p \leq 0.05)$ increased by $185.88 \%$ and $41.18 \%$ in the Biofield Energy Treated test formulation group and the untreated test formulation group, respectively as compared to the disease control group. It indicated that the Biofield Energy Treated test formulation showed better response in comparison with the untreated test formulation group. It is assumed that the increased level of primary HA titre in the Biofield Energy Treated test formulation might be due to Biofield Energy Healing (The Trivedi Effect ${ }^{\circledR}$ ) through Biofield Energy Transmission to the test formulation. The primary HA titre response was increased by $17.65 \%$ in the levamisole (reference item) group as compared to the disease control group. The response of the primary HA titre was decreased by $55.29 \%$ in the Biofield Energy Treated group per se at day -15 as compared to the disease control group. On day $20^{\text {th }}$, the secondary immune response of mean HA titre level was significantly increased by $540 \%(p \leq 0.001)$ and $166.7 \%$ in the Biofield Energy Treated test formulation group and the untreated test formulation group, respectively as compared to the disease control group. It indicated that there was an improvement of secondary HA titre in the Biofield Energy Treated test formulation than the untreated test formulation. The level of secondary HA titre was also increased significantly by $260 \%(p \leq 0.001)$ and $193 \%(p \leq 0.05)$ in the levamisole and the Biofield Energy Treated group per se at day -15, respectively as compared to the disease control group. Kawai et al. reported that the primary and secondary responses observed through the stimulation of the T-celldependent antigen [41]. Based on this, it is presumed that the Biofield Energy Treated herbomineral formulation shows the potential immunomodulatory activities which could be due to the T-cell-dependent antigen response. 
Table 1. The effect of the test formulation on primary and secondary humoral immune response in female Sprague Dawley rats.

\begin{tabular}{lll}
\hline Group & Primary HA titre & Secondary HA titre \\
\hline Disease control & $8.50 \pm 3.35$ & $10.00 \pm 0.00$ \\
Biofield Treated formulation & $24.30 \pm 8.83^{*}$ & $64.00 \pm 0.00^{* * *}$ \\
Untreated test formulation & $12.00 \pm 1.79$ & $26.67 \pm 3.37$ \\
Reference item (Levamisole) & $10.00 \pm 0.00$ & $36.00 \pm 9.63^{* * *}$ \\
Biofield Treated group per se at day -15 & $3.80 \pm 0.98$ & $29.30 \pm 7.64^{*}$ \\
\hline
\end{tabular}

HA: Hemagglutination assay. All the values are expressed as the mean \pm SEM. ${ }^{*} \mathrm{p} \leq 0.05$ and ${ }^{* * *} \mathrm{p} \leq 0.001$ as compared to the disease control.

\subsection{Effect of the Test Formulation on Paw Volume (Delayed Type Hypersensitivity)}

The effects of the Biofield Energy Treated and the untreated test formulations on delayed type hypersensitivity response (DTH) are shown in the Figure 1. The levamisole group (G5) showed significantly $(p<0.01)$ increased in paw volume as compared to the disease control group (G2). The paw volume was altered in the Biofield Energy Treated test formulation (G3), untreated test formulation (G4), and the Biofield Energy Treatment group per se at day -15 (G6) as compared to the disease control group (G2).

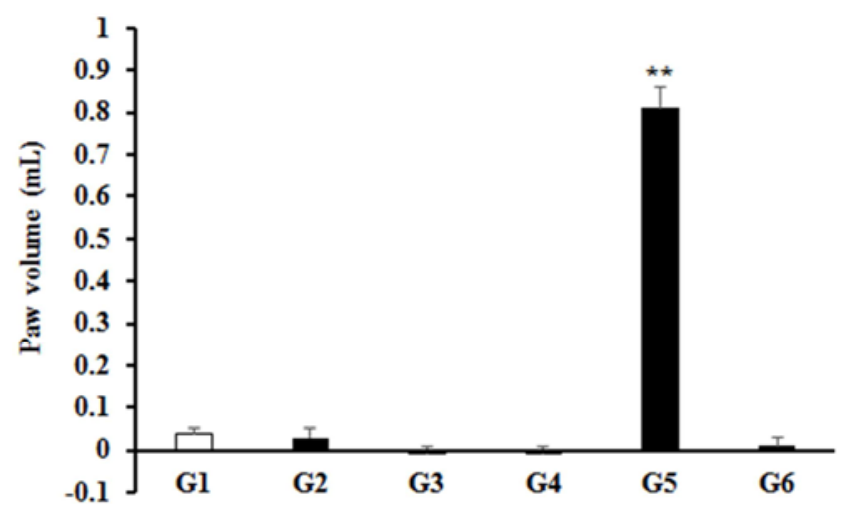

Figure 1. Effect of the test formulation on paw volume (delayed-type hypersensitivity) in female Sprague Dawley rats. G1: Normal control; G2: Disease control; G3: Biofield Energy Treated test formulation; G4: Untreated test formulation; G5: Reference item (Levamisole); G6: Biofield Energy Treated group per se at day-15. All values are expressed as the mean $\pm \operatorname{SEM}(n=6) .{ }^{* *} p \leq 0.01$ vs disease control.

\subsection{Determination of Hematological Parameters}

Various studies on nutraceutical supplementation have demonstrated the quality with respect to the body mass, reproductive timing and sociality $[42,43]$; however, plenty of studies evaluated effects of supplementation on hematologic and immunologic parameters [44]. The effect of the Biofield Energy Treated proprietary nutraceutical product on various hematological parameters is presented in the Table 2. The level of red blood corpuscle (RBC) in the disease control group (G2) was reduced by $8.94 \%$ as compared to the normal control group (G1). Besides, the level of RBC was significantly increased by $3.41 \%, 6.26 \%, 4.98 \%$, and $9.39 \%$, in the Biofield Energy Treated test formulation (G3), untreated test formulation (G4), levamisole (G5), and Biofield Energy Treated group per se at day -15 (G6), respectively as compared to the disease control group (G2). It is assumed that this improvement could be due to the influence of Biofield Energy Healing through Biofield Energy Healers. The level of hemoglobin $(\mathrm{Hb})$ was not altered in all the tested groups as compared to the both normal (G1) as well as disease control (G2) groups. The platelet count was significantly decreased by $5.34 \%$ in the disease control group (G2) as compared to the normal control (G1).

Further, the platelet count was significantly increased by $11.16 \%$ in the Biofield Energy Treated test formulation group (G3) with respect to the disease control (G2). While the platelet count was significantly decreased by $8.69 \%$ in the untreated test formulation group (G4) with respect to the disease control $(\mathrm{G} 2)$. There was an improvement of platelets counts in the G3 group as compared to the G4 group. This increased number of platelet counts in the Biofield Energy Treated formulation might be due to the influence of Biofield Energy Healing on herbomineral formulation. Besides, there was an elevation of platelets by $13.58 \%$ in the Biofield Energy Treated group per se at day -15 (G6); while it was altered in the levamisole group as compared to the disease control (G2). In the literature, it was reported that ashwagandha prevented myelosuppression and increase in platelet count and body weight [45]. Our experimental finding like increased platelet count was well corroborated with the literature observation due to the presence of ashwagandha as one of the components in the proprietary formulation. Among other hematological parameters like packed cell volume (PCV) was significantly increased by $9.70 \%$ in the Biofield Energy Treated group per se at day -15 (G6) as compared to the disease control (G2). However, the PCV did not alter in the other groups as compared to the both normal as well as disease control groups.

Moreover, the level of mean corpuscular volume (MCV) was also increased by $8.24 \%$ in the disease control (G2) as compared to the normal control (G1). The level of MCV was reduced in all the tested groups except in the Biofield Energy Treated group per se at day -15 (G6) as compared to the disease control (G2). Additionally, the level of red cell distribution width - Coefficient of Variation (RDW-CV) was increased by $13.33 \%$ in the disease control (G2) as compared to the normal control group (G1). However, the value of RDW-CV was reduced in the Biofield Energy Treated test formulation (G3), untreated test formulation (G4) and levamisole group (G5); while the value was similar in the Biofield Energy Treated group per se at day -15 (G6) as compared to the disease control (G2). It was reported that $W$. somnifera extract was non-toxic to human erythrocytes at different concentrations [46]. Our experimental results also 
suggested that the test formulation did not have any toxic effect on RBC, as no significant change was observed in different groups with respect to both the normal control and disease control groups. Besides, the minerals present in the test formulation were found to be safe, along with good therapeutic effect [47].

Table 2. Evaluation of hematology parameters assessed after Biofield Energy Treatment on the test formulation in female Sprague Dawley rats.

\begin{tabular}{|c|c|c|c|c|c|c|c|c|}
\hline Group & $\begin{array}{l}\text { RBC } \\
\left(10^{6} / \mu \mathbf{L}\right)\end{array}$ & $\begin{array}{l}\text { Hb } \\
(\mathrm{gm} / \mathrm{dL})\end{array}$ & $\begin{array}{l}\text { PCV } \\
(\%) \\
\end{array}$ & $\begin{array}{l}\text { MCV } \\
\text { (fl) } \\
\end{array}$ & $\begin{array}{l}\text { MCH } \\
(\mathrm{pg})\end{array}$ & $\begin{array}{l}\text { MCHC } \\
(\%) \\
\end{array}$ & $\begin{array}{l}\text { Platelet Count } \\
\text { (thousand } / \mathbf{m m}^{3} \text { ) }\end{array}$ & RDW-CV \\
\hline G1 & $7.72 \pm 0.23$ & $14.90 \pm 0.55$ & $43.52 \pm 1.42$ & $56.40 \pm 1.11$ & $19.28 \pm 0.38$ & $34.23 \pm 0.25$ & $1047.50 \pm 113.10$ & $0.13 \pm 0.00$ \\
\hline G2 & $7.03 \pm 0.15$ & $15.20 \pm 0.18$ & $42.87 \pm 0.58$ & $61.05 \pm 0.72$ & $21.67 \pm 0.55$ & $35.48 \pm 0.48$ & $991.67 \pm 52.01$ & $0.15 \pm 0.01$ \\
\hline G4 & $7.47 \pm 0.19$ & $14.70 \pm 0.40$ & $43.02 \pm 1.21$ & $57.70 \pm 1.00$ & $19.73 \pm 0.42$ & $34.15 \pm 0.34$ & $905.50 \pm 162.29$ & $0.14 \pm 0.00$ \\
\hline G5 & $7.38 \pm 0.40$ & $15.25 \pm 0.94$ & $44.12 \pm 2.31$ & $59.90 \pm 3.75$ & $20.72 \pm 1.30$ & $34.55 \pm 0.96$ & $996.17 \pm 136.43$ & $0.14 \pm 0.01$ \\
\hline G6 & $7.69 \pm 0.11$ & $15.78 \pm 0.33$ & $47.03 \pm 1.01$ & $61.18 \pm 0.71$ & $20.53 \pm 0.24$ & $33.55 \pm 0.13$ & $1126.33 \pm 46.76$ & $0.15 \pm 0.00$ \\
\hline
\end{tabular}

G1: Normal control; G2: Disease control; G3: Biofield Energy Treated test formulation; G4: Untreated test formulation; G5: Reference item (Levamisole); G6: Biofield Energy Treated group per se at day -15 . Hb: Hemoglobin; RBC: Red blood count; PCV: Packed cell volume; MCV: Mean corpuscular volume; MCH: Mean corpuscular hemoglobin; MCHC: Mean corpuscular hemoglobin concentration; Red cell distribution width and volume (RDW-CV).

\subsection{Evaluation of Biochemical Parameters}

The effect of the Biofield Energy Treated test formulation on different biochemical parameters is shown in the Table 3. The level of magnesium was increased by $9.31 \%$ in the Biofield Energy Treated test formulation group (G3) as compared to the disease control $(\mathrm{G} 2)$. In rest of the groups (G4 to G6), results showed an alteration of magnesium as compared to the disease control (G2). Thus, the improvement of magnesium concentration in the Biofield Energy Treated test formulation could be fruitful to the patients those who are suffering from the deficiency of magnesium. Moreover, the serum concentration of uric acid (UA) was $2.85 \pm 0.37$ $\mathrm{mg} / \mathrm{dL}$ in the normal control group and it was significantly increased by $16.49 \%$ in the disease control group (3.32 \pm $0.30 \mathrm{mg} / \mathrm{dL})$. Further, the concentration of UA was significantly reduced by $23.88 \%$ in the Biofield Energy Treated test formulation (G3); however it was increased in the untreated test formulation (G4) by $17.47 \%$ with respect to the disease control (G2). Here, the Biofield Energy Treated herbomineral formulation showed beneficial effect by reducing the concentration of UA than the untreated product. The results might be due to the positive effect of Biofield Energy Healing to the novel herbomineral product, which could be very helpful in the patients with autoimmune disorders like rheumatic arthritis and psoriasis in near future. Besides, the levels of blood urea, creatinine, calcium, phosphorous, and ions like sodium, potassium, and chloride were altered in all the experimental groups to some extent but did not show any significant difference with respect to the disease control group. Altogether, on the assessment of serum biochemistry profile, there was a significant elevation in the level of serum magnesium and significant reduction of UA in the Biofield Energy Treated test formulation (G3) as compared to the disease control (G2). The siginificant outcomes of Biofield Energy Healing on the herbomineral formulation might be due to the electromagnetic field or radiations of Healers during energy transmission process.

Table 3. Assessment of the Biofield Energy Treated and the untreated test formulations on biochemical parameters in female Sprague Dawley rats.

\begin{tabular}{|c|c|c|c|c|c|c|c|c|c|}
\hline Group & $\begin{array}{l}\text { Magnesium } \\
(\mathrm{mg} / \mathrm{dL})\end{array}$ & $\begin{array}{l}\text { Blood Urea } \\
(\mathrm{mg} / \mathrm{dL})\end{array}$ & $\begin{array}{l}\text { Creatinine } \\
(\mathrm{mg} / \mathrm{dL})\end{array}$ & $\begin{array}{l}\text { Uric Acid } \\
(\mathrm{mg} / \mathrm{dL})\end{array}$ & $\begin{array}{l}\text { Calcium } \\
(\mathrm{mg} / \mathrm{dL})\end{array}$ & $\begin{array}{l}\text { Phosphorus } \\
\text { (mg/dL) }\end{array}$ & $\mathrm{Na}^{+}(\mathrm{Meq} / \mathrm{L})$ & $\mathbf{K}^{+}(\mathbf{m E q} / \mathbf{L})$ & $\mathrm{Cl}^{-}(\mathrm{mEq} / \mathrm{L})$ \\
\hline G1 & $2.61 \pm 0.08$ & $39.37 \pm 2.25$ & $0.60 \pm 0.00$ & $2.85 \pm 0.37$ & $10.02 \pm 0.14$ & $8.00 \pm 0.20$ & $142.37 \pm 7.48$ & $5.15 \pm 0.09$ & $102.17 \pm 0.17$ \\
\hline G2 & $2.90 \pm 0.07$ & $47.30 \pm 3.61$ & $0.58 \pm 0.03$ & $3.32 \pm 0.30$ & $10.30 \pm 0.17$ & $8.93 \pm 0.31$ & $150.17 \pm 0.54$ & $5.38 \pm 0.07$ & $103.67 \pm 0.61$ \\
\hline G3 & $3.17 \pm 0.13$ & $46.32 \pm 2.61$ & $55 \pm 00.06$ & $2.68 \pm 0.15$ & $10.15 \pm 0.21$ & $8.97 \pm 0.21$ & $151.17 \pm 0.70$ & $4.97 \pm 0.11$ & $102.17 \pm 1.01$ \\
\hline G4 & $3.51 \pm 0.14$ & $53.02 \pm 2.57$ & $0.62 \pm 0.05$ & $3.90 \pm 0.40$ & $10.60 \pm 0.18$ & $10.33 \pm 0.30$ & $150.00 \pm 0.63$ & $5.53 \pm 0.22$ & $102.50 \pm 0.56$ \\
\hline G5 & $3.02 \pm 0.16$ & $51.52 \pm 3.32$ & $0.68 \pm 0.10$ & $0.68 \pm 0.10^{* * *}$ & $10.73 \pm 0.17$ & $9.08 \pm 0.24$ & $151.00 \pm 0.68$ & $5.40 \pm 0.17$ & $104.67 \pm 0.61$ \\
\hline G6 & $2.93 \pm 0.20$ & $43.00 \pm 2.18$ & $0.52 \pm 0.02$ & $3.18 \pm 0.46$ & $10.42 \pm 0.22$ & $9.20 \pm 0.42$ & $150.00 \pm 0.22$ & $5.53 \pm 0.22$ & $103.83 \pm 0.70$ \\
\hline
\end{tabular}

G1: Normal control; G2: Disease control; G3: Biofield Energy Treated test formulation; G4: Untreated test formulation; G5: Reference item (Levamisole); G6: Biofield Energy Treated group per se at day -15 . The values are represented as mean \pm SEM of 6 animals in each group. ${ }^{* * *} \mathrm{p} \leq 0.001$ (as compared to the disease control group).

\subsection{Analysis of Body Weight, Feed Intake, and Relative Organ Weight ratio (Percentage)}

The Biofield Energy Treated test formulation group (G3) showed consistent improvement of the both feed intake and body weight throughout the experiment. The absolute weight of various vital organs such as liver, lungs, kidneys, brain, heart, eyes, spleen, whole intestine, and ovaries were recorded at the end of the experiment as per standard protocol. From this, based on the final body weight (on day
22), the relative organ weight ratio (as percentage) was calculated in all the groups and the data is shown in the Table 4. Overall, results showed that the Biofield Energy Treated formulation (G3), untreated test formulation (G4), and Biofield Energy Treatment group per se at day -15 (G6) did not produce any signs of toxicity as compared to the normal control group (G1), and was found to be safe with respect to the body weight, feed intake, and most of the vital organs toxicity as compared to the normal control (G1). 
Table 4. Effect of administration of the test formulation on the relative organ weight ratio (percentage) of various vital organs in female Sprague Dawley rats.

\begin{tabular}{lllllll}
\hline Relative organ weight (\%) & G1 & G2 & G3 & G4 & G5 & G6 \\
\hline Liver & $3.11 \pm 0.13$ & $3.25 \pm 0.13$ & $3.85 \pm 0.06$ & $3.47 \pm 0.08$ & $4.02 \pm 0.10$ & $3.19 \pm 0.07$ \\
Lungs & $0.64 \pm 0.02$ & $0.73 \pm 0.03$ & $0.71 \pm 0.03$ & $0.68 \pm 0.03$ & $0.77 \pm 0.02$ & $0.75 \pm 0.02$ \\
Kidneys & $0.75 \pm 0.03$ & $0.82 \pm 0.02$ & $0.79 \pm 0.01$ & $0.80 \pm 0.02$ & $0.86 \pm 0.02$ & $0.84 \pm 0.03$ \\
Brain & $0.84 \pm 0.05$ & $0.92 \pm 0.03$ & $0.83 \pm 0.03$ & $0.78 \pm 0.03$ & $0.92 \pm 0.04$ & $0.89 \pm 0.04$ \\
Heart & $0.40 \pm 0.02$ & $0.44 \pm 0.02$ & $0.43 \pm 0.01$ & $0.41 \pm 0.02$ & $0.49 \pm 0.02$ & $0.44 \pm 0.03$ \\
Eyes & $0.11 \pm 0.01$ & $0.12 \pm 0.01$ & $0.11 \pm 0.01$ & $0.10 \pm 0.01$ & $0.19 \pm 0.07$ & $0.11 \pm 0.01$ \\
Spleen & $0.31 \pm 0.01$ & $0.36 \pm 0.02$ & $0.33 \pm 0.01$ & $0.31 \pm 0.02$ & $0.34 \pm 0.03$ & $0.34 \pm 0.01$ \\
Whole intestine & $6.25 \pm 0.20$ & $6.73 \pm 0.21$ & $9.01 \pm 0.49$ & $8.90 \pm 0.50$ & $7.39 \pm 0.27$ & $6.73 \pm 0.27$ \\
Ovaries & $0.08 \pm 0.01$ & $0.10 \pm 0.01$ & $0.09 \pm 0.01$ & $0.09 \pm 0.01$ & $0.09 \pm 0.01$ & $0.08 \pm 0.00$ \\
\hline
\end{tabular}

G1: Normal control; G2: Disease control; G3: Biofield Energy Treated test formulation; G4: Untreated test formulation; G5: Reference item (Levamisole); G6: Biofield Energy Treated group per se at day -15 .

The organ to body weight ratio is a useful index for the identification of swelling, atrophy or hypertrophy [48]. The increase in body weight or organ weight with the exposure of any compound in the animals during experiment suggested the hypertrophy, while decrease in the relative weight indicated the atrophy. The increase in body weight and organ to body weight ratio might be correlated with the sign of product toxicity, but the experimental results suggested that there was not much change in most of the vital organs, which depicts that the test product was non-toxic to the animals throughout the exposure period (22 days) at the dose of $1105.005 \mathrm{mg} / \mathrm{kg}$.

\subsection{Assessment of Gross and Histopathological Examination}

The effect of the Biofield Energy Treatment on herbomineral formulation on histopathological findings in female rats is shown in the Figure 2. No significant differences were observed either in gross or microscopic observation of the tested organs. Histopathological study results also suggest that no treatment-related histopathological findings were reported in all the experimental animals as compared to the control group. The detailed histopathological images of microscopic sections of the organs are presented in the Figure 2. Mild vacuolization in centrizonal hepatocytes was observed in few animals in the untreated test formulation group (G4;3/6). Scattered hepatocytic vacuolation was observed in few animals in the normal control $(\mathrm{G} 1 ; 2 / 6)$ and disease control $(\mathrm{G} 2 ; 1 / 6)$ groups. All other organs of animals were devoid of any microscopic changes (Figure 2).

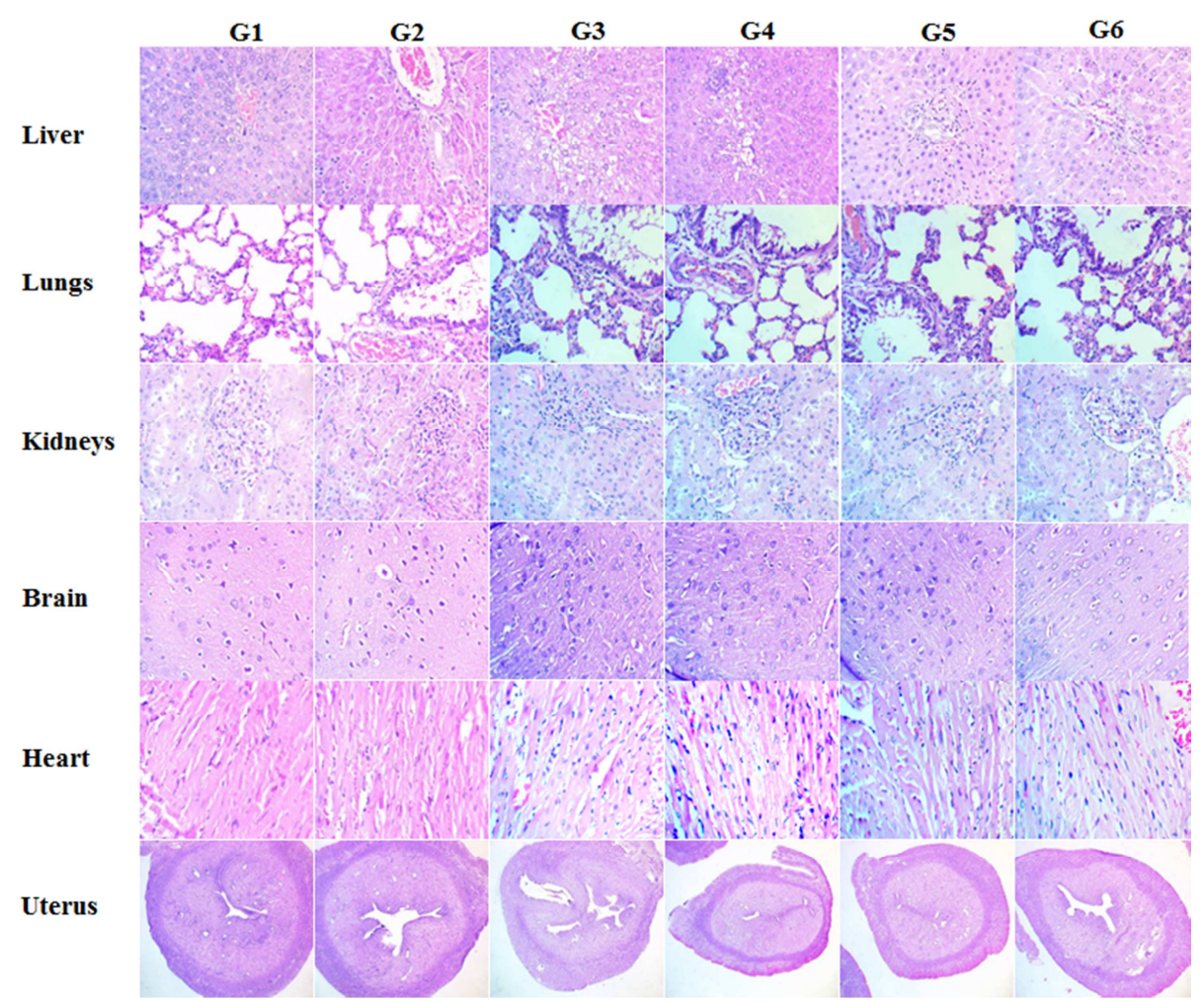

Figure 2. Histopathological photomicrograph of major organs tested after the Biofield Energy Treated test formulation for consecutive 22 days in female Sprague Dawley rats. All the tissues were sectioned transversely and stained with hematoxylin (H) and eosin (E). G1: Normal control; G2: Disease control; G3: Biofield Energy Treated test formulation; G4: Untreated test formulation; G5: Reference item (Levamisole); G6: Biofield Energy Treated group per se at day -15 . 
Biofield Energy Healing has been reported to be effective in cancer treatment by reducing the level of cytokines [49]. The National Center for Complementary/Alternative Medicine (NCCAM,) 34\% of adults in U.S. populations depends on some forms of complementary health approach, among which energy medicine is one of them. About $80 \%$ of the world population depends upon the traditional medicine for health benefits in the developing world [50]. Complementary and Alternative Medicine (CAM) has several advantages instead of the current preferred treatment approach [51]. Biofield Energy Treated herbomineral formulation might act as better immunomodulatory medicine in the near future due to its anti-inflammatory and immunomodulatory effects. Therefore, it is assumed that the Biofield Energy Treated herbomineral formulation might be considered as a safe dietary supplement for boosting the immune response.

\section{Conclusions}

The primary antibody titre level was significantly $(p \leq 0.05)$ increased by $185.88 \%$ in the Biofield Energy Treated test formulation group (G3) as compared to the disease control group (G2) and also showed better results than the untreated test formulation group (G4). The secondary antibody titre level was significantly $(p \leq 0.001)$ increased by $540 \%$ in the G3 group as compared to the G2 group. Moreover, the secondary antibody titre level was also increased significantly $(p \leq 0.05)$ by $193 \%$ in the Biofield Energy Treated group per se at day -15 (G6), as compared to the G2 group. The paw volume data showed an alteration in the G3 and G6 groups as compared to the G2 group. The level of magnesium was increased by $9.31 \%$ in the G3 group as compared to the G2 group. The platelet count was significantly increased by $11.16 \%$ in the G3 group as compared to the G2 group. Uric acid level was significantly decreased by $23.88 \%$ in the G3 group as compared to the G2 group. The Biofield Energy Treated herbomineral formulation did not show any sign of toxicity as evidenced by clinical signs and mortality. Further, no treatment-related changes were observed in the Biofield Energy Treated test formulation group with respect to the body weight and feed consumption during the experiment. The percentage of organ to body weight ratio data suggested that the Biofield Energy Treated test formulation was found to be safe with respect to the most of the vital organs toxicity. Overall, the Biofield Energy Treated herbomineral formulation showed better immune response without producing any toxicity as compared with the untreated test formulation. Thus, The Trivedi Effect ${ }^{\circledR}$ - Biofield Energy Healing has the significant capability to alter the immunomodulatory activity of the herbomineral formulation in female Sprague Dawley rats. It is then anticipitated that the Biofield Energy Treated herbomineral formulation and Biofield Energy Treatment group per se could be a more useful as immunomodulatory formulation for healthy human and in patients in the near future. Besides, it can also be utilized in organ transplants (for example kidney transplants, liver transplants and heart transplants), various autoimmune disorders such as Lupus, Addison Disease, Celiac Disease (gluten-sensitive enteropathy), Dermatomyositis, Graves' Disease, Hashimoto Thyroiditis, Multiple Sclerosis, Myasthenia Gravis, Pernicious Anemia, Aplastic Anemia, Reactive Arthritis, Rheumatoid Arthritis, Sjogren Syndrome, Systemic Lupus Erythematosus, Type 1 Diabetes, Alopecia Areata, Crohn's Disease, Fibromyalgia, Vitiligo, Psoriasis, Scleroderma, Chronic Fatigue Syndrome and Vasculitis, as well as inflammatory disorders such as Asthma, Ulcerative Colitis, Alzheimer's Disease, Atherosclerosis, Dermatitis, Diverticulitis, Hepatitis, Irritable Bowel Syndrome, Parkinson's Disease and stress etc. to modulate the immune system by improving overall health.

\section{Acknowledgements}

The authors are grateful to Dabur Research Foundation, Trivedi Science, Trivedi Global, Inc., and Trivedi Master Wellness for their support throughout the work.

\section{Conflict of Interest}

Authors declare no potential conflict of interest.

\section{References}

[1] Ziauddin M, Phansalkar N, Patki P, Diwanay S, Patwardhan B (1996) Studies on immunomodulatory effects of ashwagandha. J Ethnopharmacol 50: 69-76.

[2] De P, Dasgupta SC, Gomes A (1998) Immunopotentiating activity of immue-21; A polyherbal product. Indian J Pharmacol 30: 163-168.

[3] Huai H (2010) Ethnomedicinal analysis of toxic plants from five ethnic groups in China. Ethnobot Res Appl 8: 169-179.

[4] Modak M, Dixit P, Londhe J, Ghaskadbi S, Devasagayam TPA (2007) Indian herbs and herbal drugs used for the treatment of diabetes. J Clin Biochem Nutr 40: 163-173.

[5] Girdhari L, Rana A (2007) Withania somnifera (ashwagandha): A review. Pharmacognosy Rev 1: 129-136.

[6] Owais M, Sharad KS, Shehbaz A, Saleemuddin M (2005) Antibacterial efficacy of Withania somnifera (Ashwagandha) an indigenous medicinal plant against experimental murine salmonellosis. Phytomed 12: 229-235.

[7] Davis L, Kuttan G (2000) Immunomodulatory activity of Withania somnifera. J Ethnopharmacol 71: 193-200.

[8] Singh N, Bhalla M, de Jager P, Gilca M (2011) An overview on ashwagandha: A Rasayana (Rejuvenator) of Ayurveda. Afr J Tradit Complement Altern Med 8: 208-213.

[9] Lukác N, Massányi P (2007) Effects of trace elements on the immune system. Epidemiol Mikrobiol Imunol 56: 3-9. 
[10] Galland L (1988) Magnesium and immune function: An overview. Magnesium 7: 290-299.

[11] Mazumder PM, Pattnayak S, Parvani H, Sasmal D, Rathinavelusamy P (2012) Evaluation of immunomodulatory activity of Glycyrhiza glabra L roots in combination with zing. Asian Pac J Trop Biomed 2: S15-S20.

[12] Lutgendorf SK, Mullen-Houser E, Russell D, Degeest K, Jacobson G, Hart L, Bender D, Anderson B, Buekers TE, Goodheart MJ, Antoni MH, Sood AK, Lubaroff DM (2010) Preservation of immune function in cervical cancer patients during chemoradiation using a novel integrative approach. Brain Behav Immun 24: 1231-1240.

[13] Ironson G, Field T, Scafidi F (1996) Massage therapy is associated with enhancement of the immune system's cytotoxic capacity. Int J Neurosci 84: 205-217.

[14] Jain S, Hammerschlag R, Mills P, Cohen L, Krieger R, Vieten C, Lutgendorf S (2015) Clinical studies of biofield therapies: Summary, methodological challenges, and recommendations. Glob Adv Health Med 4: 58-66.

[15] Rubik B (2002) The biofield hypothesis: Its biophysical basis and role in medicine. J Altern Complement Med 8: 703-717.

[16] Trivedi MK, Patil S, Shettigar H, Mondal SC, Jana S (2015) The potential impact of biofield treatment on human brain tumor cells: A time-lapse video microscopy. J Integr Oncol 4: 141.

[17] Trivedi MK, Patil S, Shettigar H, Gangwar M, Jana S (2015) In vitro evaluation of biofield treatment on cancer biomarkers involved in endometrial and prostate cancer cell lines. J Cancer Sci Ther 7: 253-257.

[18] Trivedi MK, Patil S, Shettigar H, Mondal SC, Jana S (2015) In vitro evaluation of biofield treatment on Enterobacter cloacae: Impact on antimicrobial susceptibility and biotype. J Bacteriol Parasitol 6: 241.

[19] Trivedi MK, Patil S, Shettigar H, Mondal SC, Jana S (2015) Evaluation of biofield modality on viral load of hepatitis B and C Viruses. J Antivir Antiretrovir 7: 083-088.

[20] Trivedi MK, Patil S, Shettigar H, Mondal SC, Jana S (2015) An impact of biofield treatment: Antimycobacterial susceptibility potential using BACTEC 460/MGIT-TB System. Mycobact Dis 5: 189.

[21] Trivedi MK, Branton A, Trivedi D, Nayak G, Mondal SC, Jana S (2015) Antimicrobial sensitivity, biochemical characteristics and biotyping of Staphylococcus saprophyticus: An impact of biofield energy treatment. J Women's Health Care 4: 271.

[22] Trivedi MK, Branton A, Trivedi D, Nayak G, Mondal SC, Jana S (2015) Evaluation of antibiogram, genotype and phylogenetic analysis of biofield treated Nocardia otitidis. Biol Syst Open Access 4: 143.

[23] Trivedi MK, Branton A, Trivedi D, Nayak G, Charan S, Jana S (2015) Phenotyping and 16S rDNA analysis after biofield treatment on Citrobacter braakii: A urinary pathogen. J Clin Med Genom 3: 129.

[24] Trivedi MK, Patil S, Shettigar H, Bairwa K, Jana S (2015) Spectroscopic characterization of chloramphenicol and tetracycline: An impact of biofield. Pharm Anal Acta 6: 395.
[25] Trivedi MK, Patil S, Shettigar H, Bairwa K, Jana S (2015) Spectroscopic characterization of biofield treated metronidazole and tinidazole. Med Chem 5: 340-344.

[26] Trivedi MK, Patil S, Shettigar H, Bairwa K, Jana S (2015) Effect of biofield treatment on spectral properties of paracetamol and piroxicam. Chem Sci J 6: 98.

[27] Trivedi MK, Branton A, Trivedi D, Shettigar H, Bairwa K, Jana S (2015) Fourier transform infrared and ultravioletvisible spectroscopic characterization of biofield treated salicylic acid and sparfloxacin. Nat Prod Chem Res 3: 186.

[28] Trivedi MK, Branton A, Trivedi D, Nayak G, Gangwar M, Jana S (2016) Molecular analysis of biofield treated eggplant and watermelon crops. Adv Crop Sci Tech 4: 208.

[29] Trivedi MK, Branton A, Trivedi D, Nayak G, Mondal SC, Jana S (2015) Morphological characterization, quality, yield and DNA fingerprinting of biofield energy treated alphonso mango (Mangifera indica L.). Journal of Food and Nutrition Sciences 3: 245-250.

[30] Trivedi MK, Branton A, Trivedi D, Nayak G, Mondal SC, Jana S (2015) Evaluation of plant growth, yield and yield attributes of biofield energy treated mustard (Brassica juncea) and chick pea (Cicer arietinum) seeds. Agriculture, Forestry and Fisheries 4: 291-295.

[31] Trivedi MK, Branton A, Trivedi D, Nayak G, Mondal SC, Jana S (2015) Evaluation of plant growth regulator, immunity and DNA fingerprinting of biofield energy treated mustard seeds (Brassica juncea). Agriculture, Forestry and Fisheries 4: 269-274.

[32] Trivedi MK, Tallapragada RM, Branton A, Trivedi D, Nayak G, Jana S (2015) Characterization of physical and structural properties of aluminum carbide powder: Impact of biofield treatment. J Aeronaut Aerospace Eng 4: 142.

[33] Trivedi MK, Nayak G, Patil S, Tallapragada RM, Latiyal O, Jana $S$ (2015) Impact of biofield treatment on atomic and structural characteristics of barium titanate powder. Ind Eng Manage 4: 166.

[34] Trivedi MK, Patil S, Nayak G, Jana S, Latiyal O (2015) Influence of biofield treatment on physical, structural and spectral properties of boron nitride. J Material Sci Eng 4: 181.

[35] Trivedi MK, Nayak G, Patil S, Tallapragada RM, Latiyal O, Jana S (2015) Characterization of physical and structural properties of brass powder after biofield treatment. J Powder Metall Min 4: 134.

[36] Ladics GS (2007) Primary immune response to sheep red blood cells (SRBC) as the conventional T-cell dependent antibody response (TDAR) test. J Immunotoxicol 4: 149-152.

[37] OECD, OECD Guideline for Testing of Chemicals, vol. 420, Organization for Economic Cooperation and Development, Paris, France, 1992.

[38] Joharapurkar AA, Zambad SP, Wanjari MM, Umathe SN (2003) In vivo evaluation of antioxidant activity of alcoholic extract of Rubia cordifolia Linn. and its influence on ethanolinduced immunosuppression. Indian J Pharmacol 35: 232-236.

[39] Chanda S, Dave R, Kaneria M, Shukla V (2012) Acute oral toxicity of Polyalthia longifolia var. pendula leaf extract in wistar albino rats. Pharmaceutical Biol 50: 1408-1415. 
[40] Feldman BF, Zinkl JG, Jain VC. Laboratory techniques for avian hematology," in Schalm's Veterinary Hematology, $\left(5^{\text {th }}\right.$ Edn) Lippincott Williams \& Wilkins, Toronto, Canada, 2000.

[41] El Shikh MEM, El Sayed RM, Szakal AK, Tew JG (2009) TIndependent antibody responses to t-dependent antigens: A novel follicular dendritic cell-dependent activity. J Immunol 182: 3482-3491.

[42] Boutin S (1990) Food supplementation experiments with terrestrial vertebrates: Patterns, problems, and the future. Can J Zool 68: 203-220.

[43] Doonan TJ, Slade NA (1995) Effects of supplemental food on population dynamics of cotton rats, Sigmodon hispidus. Ecology 76: 814-826.

[44] Webb RE, Leslie Jr. DM, Lochmiller RL, Masters RE (2003) Immune function and hematology of male cotton rats (Sigmodon hispidus) in response to food supplementation and methionine. Comparative Biochemistry and Physiology Part A 136: 577-589.

[45] Agarwal R, Diwanay S, Patki P, Patwardhan B (1991) Studies on immunomodulatory activity of Withania somnifera (ashwagandha) extracts in experimental immune inflammation. J Ethnopharmacol 67: 27-35.

[46] Owais M, Sharad KS, Shehbaz A, Saleemuddin M (2005) Antibacterial efficacy of Withania somnifera (ashwagandha) an indigenous medicinal plant against experimental murine salmonellosis. Phytomedicine 12: 229-235.

[47] Liu L, Li N, Lei $\mathrm{T}$, Li K, Zhang Y (2014) The in vitro biological properties of $\mathrm{Mg}-\mathrm{Zn}-\mathrm{Sr}$ alloy and superiority for preparation of biodegradable intestinal anastomosis rings. Med Sci Monit 20: 1056-1066.

[48] Amresh GR, Singh PN, Rao CV (2008) Toxicological screening of traditional medicine Laghupatha (Cissampelos pareira) in experimental animals. J Ethnopharmacol 116: 454460.

[49] Gronowicz G, Secor ER, Flynn JR, Jellison ER, Kuhn LT (2015) Therapeutic touch has significant effects on mouse breast cancer metastasis and immune responses but not primary tumor size. Evid Based Complement Alternat Med 2015: 926565.

[50] Clarke TC, Black LI, Stussman BJ, Barnes PM, Nahin RL (2015) Trends in the use of complementary health approaches among adults: Unites States, 2002-2012. National health statistics reports. no 79. Hyattsville, MD: National Center for Health Statistics.

[51] Eisenberg DM, Davis RB, Ettner SL, Appel S, Wilkey S, Van Rompay M, Kessler RC (1998) Trends in alternative medicine use in the United States, 1990-1997: Results of a follow-up national survey. JAMA 280: 1569-1575. 